\title{
GÊNERO, RELIGIÃO E CULTURA \\ ORGANIZACIONAL: UMA PERSPECTIVA \\ COMPARATIVA ENTRE BRASIL E FRANÇA
}

SANTOS, Naira Pinheiro dos. Gênero, religião e cultura organizacional: uma perspectiva comparativa entre Brasil e França. São Paulo: Terceira Via, 2018.

Fernanda Marina Feitosa Coelho*

A Coleção Estudos Feministas e Religião inaugura sua série de publicações com o livro "Gênero, religião e cultura organizacional: uma perspectiva comparativa entre Brasil e França”, de Naira Pinheiro dos Santos. O livro é resultado de sua tese de doutorado, que recebeu o $2^{\circ}$. lugar no Prêmio SOTER de Teses. A autora inova ao trazer os temas de gênero e religião para dentro do universo da cultura organizacional, reconhecendo a influência do sexo e da religião de sujeitos trabalhadores de duas grandes organizações empresariais francesas em sua construção - de um lado, uma rede de hipermercados e supermercados e, de outro, um grupo químico e têxtil. Com ampla pesquisa bibliográfica e pesquisa de campo com funcionários/as, entrevistas semiestruturadas no Brasil e França e questionários com funcionários/as brasileiros/as de ambas as empresas, a obra analisa questões referentes às representações dos sexos, das religióes e da diversidade religiosa no ambiente de trabalho e de suas relações com a cultura interna e externa às empresas.

O tema da laicidade é imprescindível nessa compreensão. A escolha pelos países de análise, Brasil e França, certamente reflete a

* Doutoranda do Programa de Pós-Graduação em Ciências da Religião na Universidade Metodista de São Paulo, na área de Religião, Sociedade e Cultura, com pesquisa específica sobre Gênero, Política e Religião (Bolsista CNPq). Membro do Grupo de Pesquisa em Gênero e Religião Mandrágora/NETMAL. Endereço eletrônico: femfcoelho@gmail.com 
importância do tema. Questionando a percepção de que a França é o país mais laico do mundo, a autora reflete sobre como as subjetividades que envolvem representações religiosas e de gênero permeiam os mais diversos ambientes culturais. A obra aborda o aparentemente desencantamento da sociedade francesa contrastada com a sociedade brasileira. É nesse contexto que Naira Pinheiro dos Santos traz o tema da cultura organizacional, nos lembrando de seu papel em estimular as subjetividades dos/as trabalhadores/as e de, a partir do reconhecimento de sua diversidade, imprimir representações práticas e específicas ao ambiente interno da organização.

Interdisciplinarmente, a autora revela como, em contextos de laicidade aparentemente distintos, conflitos, tensões e tendências são produzidos e reproduzidos nas normas e práticas organizacionais pelas diversas expressões de pluralismo religioso e gênero. Para atender aos objetivos da análise proposta, a autora utiliza as identidades religiosa e de gênero como eixos de articulação para tratar aspectos específicos das culturas brasileira e francesa, visando à relevância mutuamente benéfica do entrelaçamento das análises de gênero e de religião.

O livro é composto por cinco capítulos. O primeiro capítulo, Religião e Gênero no Mundo do Trabalho: Entre o público e o privado, trata da complexidade do conceito de cultura para compreender percepções de representações sociais presentes dentro e fora do ambiente organizacional. Ainda, o capítulo questiona se a religião é verdadeiramente um fato privado para oferecer percepções acerca do lugar da religião e do gênero no mundo do trabalho como construção social. Nesse sentido, a autora trabalha as percepções dos/as questionados/as sobre as possibilidades de (in)compatibilidade entre religião e trabalho, bem como, da influência que o sexo e a religião exercem sobre a trajetória profissional. As percepções dos/as entrevistados/as compreendem diversos fatores, como relacionamento no trabalho, empregabilidade, preconceito, salários, "competências" e outros.

No segundo capítulo do livro, O Contexto Cultural Mais Amplo e Cultura Organizacional: Interações, Naira Pinheiro dos Santos analisa em que medida a religião e o gênero estruturam e justificam as práticas organizacionais a partir das transformações verificadas no mundo do 
trabalho e no discurso organizacional. Nesse capítulo, a obra aponta a presença do fator religioso e a forma como representações de gênero são mobilizadas na construção da cultura organizacional das empresas de maneira que nos permite perceber ligações entre as esferas do trabalho, da religião e da família. Seriam a religião e a família, de fato, esferas privadas?

O terceiro capítulo, intitulado Cultura Organizacional e Reprodução de Representações de Gênero e Pressupostos Religiosos nos Padrões, nas Normas e Práticas Organizacionais, trabalha as formas como a religião e o gênero influenciam não somente as culturas nacionais, como as culturas organizacionais e as relações de poder, influenciando também, portanto, as práticas, regras, padrões e procedimentos organizacionais. Nessa perspectiva, a autora busca compreender a forma que pressupostos culturais adentram as culturas organizacionais das empresas analisadas, permeando suas regras, normas e procedimentos. A tentativa de estabelecer uma correlação entre os objetivos pessoais dos/as funcionários/ as e a performance da empresa revela a diversidade de expressões religiosas de seu corpo de trabalho e também a produção e reprodução de concepções de gênero, não somente na cultura organizacional, mas nas próprias regras, padrões e procedimentos organizacionais observados.

O quarto capítulo, Gênero e Religião na Gestão da Subjetividade no Trabalho, aborda o tema da gestão de recursos humanos, da qualidade da gestão da subjetividade e das qualificações subjetivas. Naira Pinheiro dos Santos identifica mudanças recentes nas técnicas de gestão de recursos humanos a fim de incorporar competências que afetam as subjetividades de trabalhadores/as apoiadas em alguma medida sobre representações das religiões e de gênero. A autora identifica atributos que contribuem para a autonomia dos/as sujeitos/as em um contexto organizacional pós-industrial e outros atributos que são reforçados pelas religiões como sendo características tipicamente inerentes aos sexos para a construção de um quadro de funcionários/as que denota relações de poder. Com o intuito de esclarecer como essas concepções permeiam o universo da cultura organizacional no que diz respeito à gestão das emoções dos/as funcionários/as, a autora analisa o cargo de caixa de hipermercado, função hegemonicamente realizada por mulhe- 
res. Em sua análise, verifica que atributos como paciência e mansidão são estimulados por perspectivas religiosas como sendo femininos, refletindo na existência de uma divisão sexual do trabalho emocional que naturaliza competências baseando-as no sexo dos/as sujeitos/as.

O quinto capítulo, A Cultura Organizacional Enquanto Lugar de Difusão e Mediação de Tensões Sociais, aborda os paradoxos que envolvem as representações de gênero e da religião na cultura organizacional. No último capítulo de sua obra, Naira Pinheiro dos Santos busca compreender produções e reproduções das representações da religião e de gênero no contexto das duas empresas pesquisadas no Brasil e na França, verificando a existência de contradições, conflitos, tensões e tendências similares, ainda que imersas em contextos socioculturais e de laicidade diferenciados. Complexificando as análises acerca das representações de gênero e da religião, a autora demonstra como o arcaísmo e a alienação, comumente atribuídos à religião no mundo moderno, em verdade integram a cultura social mais ampla, afetando aspectos das representações de gênero que apareceram na cultura organizacional das empresas analisadas e demonstrando que o que se pensa privado efetivamente integra o público.

Diligentemente, a obra Gênero, religião e cultura organizacional: uma perspectiva comparativa entre Brasil e França demonstra como as subjetividades dos/as sujeitos/as, decorrentes de um contexto mais amplo que abarca a socialização, a cultura e concepções religiosas são estimuladas e gestadas no ambiente da cultura organizacional tanto no Brasil quanto na França, mesmo que, aparentemente, os países possuam diferentes graus de laicidade e desencantamento. A autora revela como em ambos os contextos os/as sujeitos/as são hierarquizados a depender de seu sexo, raça/etnia e religião, a exemplo da dificuldade de mulheres de origem muçulmana ascenderem no mercado de trabalho francês.

O livro oferece muitas pistas e ferramentas para a realização de novas pesquisas que busquem aprimorar a compreensão da cultura organizacional no mundo pós-moderno, como construída a partir de seus/suas trabalhadores/as enquanto sujeitos/as concretos/as e que negociam com suas culturas locais dentro e fora das empresas a partir de si mesmos/as. De fato, as representações da religião e de gênero per- 
meiam essa construção. Naira Pinheiro dos Santos discute as fronteiras que tornam o privado público e ressignifica a razão e a racionalidade que escondem traços da religião e relações de poder sob um aparente desencantamento da sociedade contemporânea.

Submetida em: 3-11-2018

Aceita em: 22-11-2018 